\title{
An Investigation of Corporate Financial Strategies Used by Banking Institutions during the Hyper-Inflationary Period in Zimbabwe
}

\author{
Richard Mhlanga \\ Graduate School of Business, National University of science \& Technology, Zimbabwe \\ Mabutho Sibanda \\ School of Accounting, Economics \& Finance, University of KwaZulu-Natal, South Africa
}

\section{Doi:10.5901/mjss.2013.v4n13p609}

\section{Abstract}

The corporate investment and financing decision plays a pivotal role in the financial management of firms operating under any economic environment. This paper investigates and analyses corporate financial strategies employed by banking institutions during the hyperinflationary period in Zimbabwe. Descriptive statistics are employed and the results show that activity was high in the market for corporate control between 1997 and 2007. Despite economic meltdown and inflationary trends, evidence suggests that the banking industry in Zimbabwe recorded a phenomenal increase in public listings during the same period. Other capital raising activities like venture capital funding, rights issues and debt finance have also been extensively used by the banking industry. Dividend policy amongst most banking institutions showed a significant decline towards 2007 as banks sought to retain funds to sustain operations. These findings provide a view that firms follow a life cycle in the determination of the optimal investment and financing decisions even when operating in an uncertain environment. The paper concludes by suggesting several strategies to improve financial soundness of banks operating in an inflationary environment.

Keywords: hyperinflation, Zimbabwe, banking institutions, economic growth, financial strategy

\section{Introduction}

The financial sector in Zimbabwe has significantly transformed since the early 1990s amid increased competition in the sector. This transformation has been brought about by the Bretton Woods led economic reforms in 1991 that liberalized the financial sector. Among the major developments in the financial sector was the massive growth of 240 percent in the number commercial banking institutions with the number of institutions increasing from five in 1991 to seventeen in 2000. This growth came amid declining economic activity propelled by recurrent droughts and the collapse of the productive manufacturing and agricultural sectors. The magnitude of the economic meltdown is reflected in GDP growth declining from 7.1 percent in 1990 to a negative 7.3 percent in 2000 (RBZ, 2008).

In the period 2000 to 2007 rationalization and consolidation of banking institutions occurred. During this period, hyperinflation besieged the country and the number of commercial banks dropped from seventeen to fourteen by the end of 2007. A total of twenty-eight (28) banking institutions were fully operational in 2007 comprising fourteen (14) commercial banks, five (5) merchant banks, four (4) discount houses, four (4) building societies and (1) finance house (RBZ, 2008). Five commercial banks collapsed in 2004 and 2005 alone. Two new banks were registered in the same period including a state owned savings bank.

Financial strategy is the raising of funds needed by an organization in the most appropriate manner and managing the employment of those funds within the organization (R. Bender \& Ward, 2009). This includes the decision to reinvest or distribute any subsequent profits generated. Given that the primary objective of a firm is to create and maximize shareholder value, firms need appropriate financial strategies during different stages of their life cycle. In essence, a financial strategy comprises two main building blocks: (i) raising funds needed by the firm in a cost effective manner and (ii) the employment and management of those funds. This entails the decision to reinvest or return any subsequent profits to shareholders. Shareholders realize return through cash returned to them as dividends and capital gains. Appropriate financial strategies encompasses transactions such as raising seed-capital, start-up capital, flotation on a stock exchange, managing for corporate control and dividend payout policies. For a firm to survive any operating environment, it needs to formulate appropriate strategies to beat competition in the sector in which it operates. This study 
therefore, seeks to establish the financial strategies used by the banking industry in Zimbabwe to weather the harsh economic environment characterized by incredible hyperinflation of 66212 percent as at 31 December 2007 (RBZ, 2008). The hyperinflation period ended in 2009 after the adoption of the multiple currency system.

\section{Problem Statement}

Banks in Zimbabwe faced a harsh operating environment during the country's economic decay in the period 2000 to 2008. Inflation soared to six digit levels forcing several banks to collapse. The collapse of banks came amid a dwindling deposit base as customers preferred using cash to savings products offered by financial institutions. However, some banks survived the hyper-inflationary period and managed the transition to the multiple currency system in 2009. The study therefore seeks to investigate corporate financial strategies used by these banks to survive the economic meltdown in Zimbabwe.

\section{Objectives of the study}

This seeks to:

i. analyze and compare the growth trends in the number of commercial banking institutions spanning 1997 to 2007 ,

ii. $\quad$ investigate and classify corporate financial strategies used by commercial banking institutions spanning 1997 to 2007 ,

iii. analyze corporate financial strategies used by commercial banking institutions during the period 1997 to 2007, and

iv. provide recommendations for improving corporate financial strategies in a hyperinflationary environment.

\section{Background to the study}

Zimbabwe's banking history dates back to the ninth century when Standard Chartered Bank Zimbabwe Limited opened its doors to the public in 1892 in Zimbabwe's now second largest City of Bulawayo. At the time, the bank was called The Standard Bank of British South Africa. The banking industry then grew to an oligopoly state right up to the early 1990s when the country embarked on financial sector reforms. These reforms were known as financial liberalization, and arose from the Economic Structural Adjustment Programme (ESAP) sponsored by the International Monetary Fund (IMF). The Reserve Bank of Zimbabwe administers all monetary and exchange controls and is the sole bank of issue.

Five commercial banking institutions operated in Zimbabwe in 1990 of which none of them was established in post-independence Zimbabwe. These institutions we established between 1892 and 1980. The period prior to 1991 would not be considered as the economy is perceived to have been stable and socialist oriented. During this period, the government focused more on social investment by building schools, hospitals and rural development. This contributed, on average, 45 percent of the country's GDP in the 1980s (World Bank 2010). Government policy changed in 1991 when Economic Structural Adjustment Programme (ESAP) was introduced to curb public spending. Inflation, which was below 15 percent range in the 1980 s rose from 15.5 percent in 1990 to 71.9 percent in 2001 . The increases became rapid in the periods 2002 to 2007, rising from 133.2 percent in 2002 to 66212 percent in 2007.

Corporate financial strategy for banking institutions prior to financial liberalization in 1991 seems to have been primarily based on the need to maintain adequate capitalization as the country employed socialist economic policies. Adequate capitalization enables banking institutions to expand their loans portfolios to enhance interest income (Cecchetti, 2008). The traditional banking style advocates for greater proportions of revenue to be generated from interest income than from otherwise. Modern banking on the other hand seems to suggest that banks should be more innovative and enhance non-interest income streams. Banking institutions sought to achieve client satisfaction and retention as more players entered the financial sector. During this period, interest rates and inflation levels were fairly stable below 20 percent (RBZ, 2008). Consequently, the banking industry was fairly stable during the same period. However, the global collapse of Bank of Credit and Commerce International (BCCl) in 1991 created a wave of uncertainty in the industry. The bank had operations in Zimbabwe which culminated from a joint venture with the government in 1980. To avoid systemic risk, the government acted swiftly to restore confidence in the sector by bailing out $\mathrm{BCCl}$ operations in Zimbabwe. The government took over the foreign owned stake in $\mathrm{BCCl}$ in 1991 to form Commercial Bank of Zimbabwe Limited (CBZ). The collapse of a bank creates a contagion effect in the industry and 
possible lack of confidence in the entire banking system (Saunders \& Cornett, 2008). CBZ became a 100 percent state owned institution in 1991.

In 1992, National Merchant Bank Limited (NMB), the country's first indigenous bank was established. The pilot indigenous bank was a success, as the bank existed at the time of writing this paper. Numerous banking institutions mushroomed within a decade and as of December 2000, seventeen commercial banks were fully registered in Zimbabwe. Corporate financial strategies in the banking industry during the period $1991-2000$ were diverse. The emergence of new banking institutions required strong capitalization levels to sustain the volume of business in a potentially competitive industry. New banking institutions had to raise both equity capital and debt capital to establish their businesses. Furthermore, it seems an aggressive approach to business was necessary in order to get a slice of the cake from an industry with traditionally sound banking institutions. This entailed among other strategies, generous dividend policies, entering into strategic partnerships and engaging in horizontal and conglomerate mergers within the industry.

According to the RBZ statistics, the period 1990 to 2000, inflation levels averaged 32.5 percent. In absolute terms inflation rose from 24.3 percent in 1991 to 59 percent in 2000. Inflation peaked in 1999 at 58.5 percent. The increases became rapid and unprecedented in the periods 2002 to 2007, rising from 71.9 percent in 2001 to 66212 percent in 2007(RBZ, 2008).

Given the sharp rise in inflation levels, firms would logically invest in inventory and real assets to maintain shareholder value. Real assets are however illiquid and in case of a liquidity crunch the assets may have to be disposed of at discounted fire sale prices (Saunders \& Cornett, 2008). A major impediment facing companies operating in Zimbabwe during the period under review was low capacity utilization due to diverse reasons including the acute shortage of foreign currency, price controls, and severe declines in agricultural output. For instance between 2000 and December 2007, agriculture output dropped by 51 percent and industrial production dropped by 47 percent. In light of this, banking institutions had to map survival strategies to remain in business during this period of economic meltdown.

According to the RBZ (2008), the primary factor driving inflation in Zimbabwe was the broad money supply (M3) growth. Money supply growth increased from 1638.4 percent in January 2007 to 24463.6 percent in October 2007. The rapid growth in broad money supply was attributable to an annual expansion in domestic credit of 37894.6 percent, largely driven by growth in credit to the private sector of 52963.6 percent. Furthermore, Zimbabwe's broad money supply increased an average 48.3 percent in 1997-2001, 520 percent in 2005, and 1579.5 percent in 2006 . The growth in credit to the private sector was mainly driven by government loans through the country's commercial banks to fund the land reform program. Industrial production also acquired bulk loans in local currency to finance imports. This exacerbated the scarcity of foreign exchange situation and led to a thriving parallel market.

\section{Methodology}

As this study attempts to investigate and analyze corporate financial strategies of commercial and banking institutions in a hyperinflationary environment, it is based on historic data from 1991 to 2007. Data was obtained from public sources such as the Reserve Bank of Zimbabwe various publications and banking institutions annual reports. Information of some unlisted banks was difficult to obtain but major listed banking institutions provide a surrogate for the entire banking industry in Zimbabwe, hence only the latter were used in this study. For the purpose of this study a comparative analysis of the 1991-2000 period and 2001-2007 is made. Economic growth indicators are used for the period 1990 to 2007. 2008 is omitted from the study due to insufficient data and the fact that the country's capital markets were inactive as trading on the Zimbabwe Stock Exchange was suspended that year. We use descriptive statistics guided by an analytic approach to ascertain corporate financial strategies used by the banking sector in Zimbabwe.

\section{Discussion}

In this study, corporate financial strategies used by banks have been broken down into sources of capital and distribution of surplus cash resources and these are discussed in turn below.

\subsection{Start-up sources of capital}

Capital may be defined as equity, debt and hybrid securities raised by a firm to meet financial requirements of long-term nature. The asset side of the balance sheet (investment decision) takes center stage prior to making the financing 
decision (Brealey \& Myers, 2003). Therefore, the investment side influences the mixture of financing instruments that a firm could use. The nature of the banking industry requires substantial capital to finance start-up operations. Major capital expenditures include investment in software and hardware and maintaining cash reserves to act as a cushion against losses. Start-up businesses require seed capital at pre-launch stage (R. Bender \& Ward, 2009). Since banking products are not a new concept in Zimbabwe, it seems new entrants still required expenditure on market research to determine whether there is truly a viable business opportunity in the industry. Most banking outfits (like any firm) need capital to fund operational expenses and high levels of one-off launch-associated costs. Unlike ordinary firms, bank capital is divided into Tier I and Tier II. Tier I capital is primary or core capital; Tier II capital is supplementary capital. Consequently, the total capital that a bank holds is defined as the sum of Tier I and Tier II capitals (Saunders \& Cornett, 2008). Capital invested at launch stage is known as start-up capital (R. Bender \& Ward, 2009). Existing literature shows that both start-up and seed-capital are enormously risky although the former is less risky. Investors at this stage of business are venture capitalists, business angels and corporate venturing. Venture capital investors have to appreciate the risks involved in startup businesses. Such risks include potential for loss of their investment. However, the venture capital finance is optimal only when the aggressive continuation strategy is not too profitable, ex ante (Winton \& Yerramilli, 2008). In this regard, a start-up firm has alternative sources of finance, including bank finance and principal owners' equity.

Venture capital funding has been the main source of start-up capital for banking institutions in Zimbabwe during the period 1991 to 2000. All banking institutions acquired venture capital funds. Venture capital investors are generally perceived to be risk takers. However, venture capitalists generally act in a risk-averse manner, in as much as they manage their risks by limiting their investment portfolios to sectors they understand (R. Bender \& Ward, 2009). These ideal equity investors for start-up businesses must appreciate the risks involved, including the potential for total loss of their investment, and must want to receive their financial return in the form of capital gains. This study shows that the average age of venture capital investment in the banking industry was five years for the decade ending December 2002. Most venture capitalists existed on initial public offerings (IPOs). This is further discussed under IPOs as a financial strategy parameter.

Table 1: New market players in the banking industry in Zimbabwe

\begin{tabular}{lcccc}
\hline \multicolumn{1}{c}{ Period } & $1991-1995$ & $1996-2000$ & $2001-2005$ & $2006-2007$ \\
Number of banking institutions & 15 & 17 & 26 & 23 \\
New registrations & 2 & 13 & 2 & 0 \\
Total number of banks & 17 & 30 & 30 & 0 \\
Growth in number of banks (\%) & 13 & 76 & 8 & 0 \\
Average annual GDP Growth (\%)* & 2.8384 & 1.557 & -5.642 & -4.6875 \\
Average annual inflation rate (\%)* & 26.69 & 30.46 & 195 & 627.25 \\
\hline
\end{tabular}

Source: Average of World Bank Group figures

In the period 1998-1999 two merchant banks collapsed. These are United Merchant Bank and Universal Merchant Bank. The period 2001-2005 witnessed the closure of five banks. The table above shows a 13 percent growth in banking institutions against an average GDP growth of 2.84 percent and average inflation of 26.69 percent during the period 1991-1995. The period 1996-2000 recorded a sharp growth in banking institutions of 76 percent and average inflation of 195 percent against declining GDP growth which averaged 1.56 percent. The period 2001-5 recorded an average decline in GDP of negative 5.64 percent amid spiraling inflation which averaged 195 percent during the same period. The number of banks increased only by 8 percent during the same period. Inflation trends worsened in 2006-7 period averaging 627.25 percent against negative 4.69 percent GDP growth.

Corporate venturing is another way start-up businesses are financed. This alternative source of funding, according to Bender and Ward (2002) provide start-up businesses (banking institutions in this case) with useful financial support and gives access to a wide range of useful business contacts. Growing competition forced banks to enter into strategic partnerships with listed corporates in Zimbabwe. This relationship enabled banks to access core deposits from corporate businesses and use the latter's infrastructure to roll out retailing banking units. These banking institutions were five years from founding when they embarked on corporate relationships. At this stage, these banks sought public listing which enabled venture capital investors to cash-out their shareholdings. This is consistent with the financial economic theory that venture capitalist firms would exit at the growth phase of the business to concentrate their effort on new businesses 
(R Bender \& Ward, 2002). However, all these banks were closed by RBZ in 2004 due to either illiquidity or imprudent banking behavior in contrast to the perceived financial support and access to a wide range of useful banking contacts provided by corporate investors.

\subsection{Initial Public Offers}

Bender and Ward (2002) assert that a company might seek a listing due to two reasons. They classify the first reason as "cash in". Cash in float is one that is done for raising funds for the company's continued expansion. In other words cash in floats are for growth companies, which issue shares for the funds they need. The second reason is classified as "cash out". According to Bender and Ward (2002), in cash out float, the main purpose of listing is to obtain exit for some existing shareholders. Existing literature suggests that firms at a growth phase of their life cycle usually want to either cash in to finance expansionary programmes or cash out to provide exit for start-up investors (R Bender \& Ward, 2002). Consequently, initial venture capitalist investors will be keen to realize their capital gains in order to enable them to reinvest in other start-up businesses. This assertion is also shared by Ogden, Jen and O'Connor (2003) in their study of the characteristics of IPO firms from 1991-2000 in USA. Their study showed that of the 3,923 IPOs, 45 percent were venture backed. The average firm age from the founding year to IPO date was 6.9 years compared to 8.3 years for nonventure-backed firms. The earlier exit showed by venture backed firms shows the extent in which initial venture investors would like to cash out. IPOs therefore provide an exit form for initial investors and continued funding during the period of high growth.

Another reason for IPOs to flourish is due to hot IPO markets. Hot IPO markets follow a from time variation in adverse selection (Yung, Colak, \& Wang, 2008). They argue that the increase in number of firms going public is a wave. This wave is influenced mainly by positive economic shocks. In a country that is characterized by hyperinflation, the only positive economic shocks may be attributed to a booming stock market. This provides firms with an opportunity to raise relatively cheaper capital from the public. IPO investors would be optimistic that the share price would increase upon listing due to asset re-pricing influenced by inflationary pressures.

A summary of banks that listed on the Zimbabwe Stock Exchange during the period 1991-2007 is shown in Table 2 below.

Table 2: Banks listed on the Zimbabwe Stock Exchange 1991 -2007

\begin{tabular}{lcccc}
\hline \multicolumn{1}{c}{ Period } & 1991-1995 & 1996-2000 & 2001-2005 & 2006-2007 \\
Old listed banking institutions & 3 & 5 & 5 & 6 \\
New listings/IPOs & 2 & 1 & 4 & 1 \\
Total number of banks listed & 5 & 5 & 9 & 7 \\
Growth in number of bank listings (\%) & 67 & 20 & 80 & -22 \\
Growth in banking institutions (\%) & 13 & 76 & 8 & 0 \\
Average GDP Growth (\%) & 2.8 & 1.6 & -5.6 & -4.7 \\
Average inflation rate (\%) & 26.69 & 30.46 & 195 & 627.25 \\
\hline
\end{tabular}

Source: Average of World Bank Group figures, RBZ reports and Author's findings

Four banks listed on the stock exchange between 2001 and 2004. The growth rate of stock exchange listings became rapid (80 percent) during the period 2001 to 2005. During this period the increase in the number of banks was only 8 percent. The highest number of banks listed on the stock exchange peaked when economic indicators seemed unfavorable. The period 2001-5 recorded an incredible five year average annual decline of 5.64 percent in GDP and an average of 195 percent inflation. It would seem that the inflationary trends motivated banks to seek external capital through IPOs to expand their operations and to improve their ratings.

\subsection{Rights issues}

Firms usually issue new shares to existing shareholders in what Brealey and Myers (2003) call privileged subscriptions or rights issues. Such an offer gives the firm's existing shareholders the right of first refusal. A rights issue that gives the shareholder one right for each share held is known as a "New York right"(Brealey \& Myers, 2003). On the other hand a rights issue, where a shareholder needs one right to purchase one new share is known as a "Philadelphia right". Bender 
and Ward (2002), state that existing publicly quoted firms may issue new shares through a direct offer to outside investors at the current market price of the shares. This is known as a Secondary Public Offering. In light of the need to maintain capitalization levels with inflationary trends, two banks embarked on a capital raising exercise through a rights offer between March 2005 to raise capital and in September 2006. Thus, rights issues were not common in the banking sector during the hyperinflation period.

\subsection{Debt finance}

Banking institutions are by their nature highly levered. A bank is ordinarily in the business of accepting deposits and lending. Deposits are a liability to the bank whereas loans and facilities granted represent the firm's assets. According to Saunders and Cornett (2008), US Banks as in June 2006 had 10 percent equity capital, 67 percent deposits, 20 percent borrowing and 3 percent other liabilities. This proves that banking institutions core business is highly levered. To avert 100 percent external funding in the banking sector, financial authorities worldwide use key financial ratios that include capital adequacy, loan-to-deposit ratios and monitors Tier 1 and II capital. In this way banks remain with a buffer to cushion them from bank runs and illiquidity. Also deposit insurance is used to protect depositors. The RBZ revised minimum capital requirements of financial institutions with effect from 30 September 2006. In US dollar terms, the new capital requirements were US\$10 million for commercial banks, US\$5 million for discount houses and US\$1 million for asset management firms. This posed a big challenge for banking institutions hence they needed to restructure, consolidate and merge businesses in order to comply with minimum capital requirements. Prior to pegging minimum capital requirements in hard currency (US\$), banking institutions faced a moving target capital as RBZ strived to maintain a reasonable capital threshold in a hyper inflationary environment.

\subsection{Mergers and acquisitions}

Mergers, acquisitions, takeovers and buyouts reflect the workings of the market for corporate control (Ogden, Jen, Philip, \& O'Connor, 2003). In a merger, two separate corporations combine to form a single entity while a consolidation both firms cease to exist, and a new corporation is established with a new name, a new board and new management team. Several motives are given for mergers or acquisitions. These include operating synergy, financial synergy and diversification, bankruptcy avoidance, financial slack, hubris and self-interest of the bidder's management (Ogden et al., 2003). Existing literature has identified three broad categories of mergers. A vertical merger occurs between two firms that had been doing business in different stages of the production process in a given industry. A conglomerate merger on the other hand involves the combination of two firms in unrelated industries. Lastly a horizontal merger entails two firms that have been competitors in the same line of business.

The market values of financial conglomerates engaging in multiple activities are lower if those financial conglomerates were broken into financial intermediaries specializing in individual activities (Leaven \& Levine, 2007). Given that the values of financial conglomerates are lower than the specialized financial institutions, we investigate the need for conglomerate mergers in a hyper inflationary environment. The estimated value gains from bank mergers stem from the opportunity to cut costs by eliminating overlapping operations and consolidating backroom operations (Houston, James, \& Ryngaert, 2001). This argument asserts that a typical bank merger, estimated revenue enhancements are significantly less important. A merger of two or more banks would be classified as horizontal merger. On the other hand when a banking institution acquires another specialized institution, this would be classified as a conglomerate merger.

An analysis of the banking industry shows several events occurred in the market for corporate control during the period under review. The period 1991 to 2000 witnessed three mergers and acquisitions. An analysis of CBZ's conglomerate merger activities shows the trends in the market for corporate control in Zimbabwe. The first deal involved the government's acquisition of BCCl's one hundred percent stake in 1991 which led to the formation of CBZ. According to finance theory, the motive for this deal could be classified as bankruptcy avoidance for the target. BCCl operations had collapsed worldwide and the government took over the bank to avoid bankruptcy and systemic risk in the banking industry. The bank conducted an IPO and listed on the ZSE in 1998.

In 1997, a horizontal merger between two merchant banks was done amid an influx of new players in the industry. Operating synergy could be attributed as the main motive for this merger. The merger enabled the new entity to diversify into asset management by acquiring other financial institutions in the country and later diversifying regionally and listing in Botswana in 2001. In late 1990s two more banks provided support for the vertical integration in mergers and acquisitions. These banks acquired interests in stockbroking and asset management and eventually built conglomerate 
financial institutions through broad diversification since the two targets were not in the same line of business.

Activity in the market for corporate control remained slack between 2001 and 2003. The newly listed banking firms concentrated more on increasing market share through innovative products and services to counter inflation. However this could not be sustained in the industry characterized poor bank supervision. A sudden policy change that came in with the appointment of the new Reserve Bank Governor in December 2003 brought immense changes to the banking industry. The three newly listed banks and two other non-listed banks were placed under the management of a curator in 2004. These institutions were placed under curatorship mainly because of liquidity problems exacerbated by changes in the monetary policy. The monetary policy restricted the use of the discount window by banking institutions in December 2003 and as such banks with insufficient liquid assets experienced liquidity constraints and subsequently bank runs. The operations of these banks were merged to form a new entity called Zimbabwe Allied Banking Group (ZABG) in 2005. The horizontal mergers in the industry were driven by the need to save failing banks and hence protect public confidence in the industry. The results of the analysis also suggest that the economic crisis led to increases in mergers in the banking industry. The market for corporate control intensified with inflation rising fast and subsequently banks embarked on rebranding to attract the ever dwindling deposit base.

\subsection{Dividend policy}

The payment of cash dividends is the logical method of distributing cash that is no longer required by a firm to its investors. The payment of dividends is constrained by two factors, namely the ability to afford cash outflow from the company and the existence of distributable profits (R. Bender \& Ward, 2009). In 1961 Modigliani and Miller presented a theoretical framework that asserted that under an ideal capital market, a dividend policy is irrelevant as long as the firm's capital investments are fixed (Ogden et al., 2003). In theory, firms would pay dividends to prop up their share prices. An ideal market comprises perfect market conditions coupled by modest economic indicators like stable inflation and interest rates. Real world factors include principal-agent conflicts, information asymmetry, taxes and transaction costs. In addition to the real world factors discussed by Modigliani and Miller, some capitalist economies seldom operate within the confines of these factors. Consequently Modigliani and Millers' assertions may not hold in an inflationary environment. Zimbabwean banks have been operating in an environment characterized by high inflation levels and interest rates. Given the hyper inflationary conditions in the country, it would be interesting to investigate the trends in dividend payments by firms as a financial corporate strategy.

Existing financial economics literature provides alternatives ways of returning cash to shareholders include stock splits and share buybacks. Diverse reasons are given for a shift from cash dividends to share repurchases globally. Presumably dividends are taxed higher than capital gains hence rendering them less valuable. On the other hand, repurchases are a province of dividends and primarily increase the already high cash payout of dividend payers. In this regard firms may substitute cash dividends for share repurchases and both can be viewed from a dividend perspective.

Nine commercial banking institutions were listed on the Zimbabwe Stock Exchange in 2004 and six by the end of 2007. Three banks previously listed on the exchange collapsed or were paced under curatorship between 2004 and 2007. These listed banking institutions provide a proxy for analyzing dividend payments in the banking industry in Zimbabwe. Of the six listed banks in 2007 none of the banks paid a dividend. Various reasons were given for nonpayment of dividends. Most banks cited the difficult economic environment and need for capital consolidation in order to safeguard business underwriting capacity. One bank declared a scrip and cash dividends, in 2004 a bonus issue and had cash dividends thereafter. Nil dividend policies from 2005 to 2007 are in line with inflationary and economic growth trends that reached unprecedented levels during this period. Banks retained cash for expansion within the financial sector. The results of the above analysis suggest that firms do not pay dividends in a hyper inflationary environment mainly as a survival strategy. Banks retained their profits to finance existing operations and to exploit acquisition opportunities in the industry.

\section{Conclusion}

This study shows that an influx of banking institutions was experienced in Zimbabwe during the period 1991 to 2000. Twelve commercial banks were established during this period. This represents a 240 percent growth from the initial establishment of five commercial banks in 1990. However despite this phenomenal growth, two newly formed banks collapsed between 1998 and 1999. The number of banking institutions however, declined in 2005 after the closure of five institutions during 2004-5. Only two banking institutions were established after 2002, including the commercialization of a 
state owned post office savings institution in 2005. Non-registration of new banks in 2006-7 was due to difficult operating environment in the banking industry which was further exacerbated by the hyper inflationary environment. The study also shows that all new banking institutions used either venture capital or corporate funding at the start-up phase. An influx of new listings in the banking industry was recorded during the period 2000-7. This enabled banking institutions to raise additional capital for growth purposes. Rights issues were however few during the period 2000-7 as banks preferred organic growth to external growth after IPO. These findings on raising capital at different phases of life cycles is consistent with the financial economic literature which postulates that firms tend to rely on venture capital at establishment, IPO funds at growth phase and internally generated funds thereafter. Furthermore, banks preferred to retain all their profits in 2005-7 to either sustain their operations or to consolidate their positions in the industry. Market for corporate control was active during the period 2000-7 with thirteen mergers and acquisitions. Of these, two were vertical, two horizontal and nine were conglomerate mergers. The findings on dividend policy and market for corporate control are also consistent with the financial economic literature which states that firms operating in an uncertain business and economic environment are likely to pay less cash dividends while they jostle to acquire other industry players to consolidate their market share.

Overall, this study shows that banking institutions tend to benefit from economic turbulence hence the phenomenal growth of the industry during the hyperinflationary period. On the other hand, corporate financial strategy generally remains in line with that of firms operating in different economic cycles, specifically in recessionary environments. Lessons from the study show that the following corporate financial strategies are applicable to firms operating in hyperinflationary environments:

- Use more of venture and corporate funding at start-up phase.

- List on a recognized exchange to access additional external capital.

- Embark on rights issues where feasible.

- Don't pay dividends.

- Use surplus funds to consolidate the firm's operations through mergers and acquisitions.

Lastly, the study explored and unveiled opportunities and challenges that faced Zimbabwean banking institutions between 1990 and 2008. The period between 1990 and 2000 witnessed rampant growth in the banking industry amid inflationary environment. In contrast, the period between 2001 and 2008 unveiled a host of challenges that led to the near collapse of the banking industry. Hyperinflation was a major threat to the banking industry as capital and public savings and investments got eroded rapidly. The challenges faced by banks during this period were bolstered by the unpredictable monetary policy stance employed by the Reserve Bank of Zimbabwe.

\section{References}

Bender, R., \& Ward, K. (2002). Corporate Financial Strategy (2nd ed.). Great Britain: Elsevier Butterworth Heinemann.

Bender, R., \& Ward, K. (2009). Corporate Financial Strategy (2nd ed.). Hungary: Elsevier Butterworth Heinemann.

Brealey, R. A., \& Myers, S. C. (2003). Financing and Risk Management (6th ed.). United States of America: McGraw-Hill.

Cecchetti, S. G. (2008). Money, Banking, and Financial Markets (2nd ed. Vol. 2). New York: McGraw-Hill.

Houston, J. F., James, C. M., \& Ryngaert, M. D. (2001). Where do merger gains come from? Bank mergers from the perspective of insiders and outsiders. Journal of Financial Economics, 60, 285-331.

Leaven, L., \& Levine, R. (2007). Is there a diversification discount in financial conglomerates? Journal of Financial Economics, 85, 331367.

Ogden, J. P., Jen, F. C., Philip, F., \& O'Connor, P. F. (2003). Advanced Corporate Finance- Policies and Strategies. United States of America: Pearson Education Inc.

RBZ. (2008). Monetary Policy Statement Harare: Reserve Bank of Zimbabwe.

Saunders, A., \& Cornett, M. M. (2008). Financial Institutions Management: a Risk Management approach. Singapore: McGraw-Hill Winton, A., \& Yerramilli, V. (2008). Entreprenual Finance: Banks versus venture capital. Journal of Financial Economics, 88, 51-79. Yung, C., Colak, G., \& Wang, W. (2008). Cycles in the IPO market. Journal of Financial Economics, 89, 192-208. 